\title{
Rancangan Materi Statistika Terintegrasi Nilai dan Budaya Keislaman: Suatu Kerangka Konseptual
}

\author{
Khairiani Idris \\ Jurusan Tadris Matematika, Fakultas Tarbiyah dan Ilmu Keguruan, \\ Institut Agama Islam Negeri Lhokseumawe \\ Jalan Medan-Banda Aceh KM 275 No.1 Buket Rata-Lhokseumawe, Aceh 24351 \\ Email:khairiani@iainlhokseumawe.ac.id
}

Article History:

Received: 29-10-2020; Received in Revised: 25-01-2021; Accepted: 07-02-2021

\begin{abstract}
Lecturers in the Islamic Universities in Indonesia have hardly found statistics textbooks that emphasize statistical literacy and use data contexts not contradict Islamic cultures. This is a research and development study aimed at developing a conceptual framework that can be referred to in designing statistics learning materials based on statistical literacy integrated with Islamic values and cultures. The phases of the study included problem analysis on statistics learning materials in Indonesia, literature reviews, developing the initial stage of a conceptual framework, validation, and revision. The result was the conceptual framework composed of five components: a) learning statistics for a virtuous character, b) learning statistics gradually and in sequences, c) learning using useful contexts, d) knowing istiqra' in inferential statistics, and e) developing critical attitude towards quantitative information. Each component was subsequently elaborated into several points as examples in designing statistics learning materials.
\end{abstract}

Keywords: Integration of Islamic Values; Conceptual Framework; Statistical Literacy; Statistics for Islamic Universities.

\begin{abstract}
Abstrak
Dosen statistika di Perguruan Tinggi Keagamaan Islam di Indonesia umunya sulit menemukan buku rujukan statistika berbasis literasi statistik dan menyajikan konteks data yang tidak bertentangan dengan nilai dan budaya keislaman. Penelitian ini mencoba mengembangkan suatu kerangka konseptual yang dapat dijadikan acuan untuk mendesain materi statistika berbasis literasi statistik yang terintegrasi nilai dan budaya keislaman. Tahapan penelitian mencakup analisis permasalahan tentang materi perkuliahan statistika di Indonesia, kajian literatur, pengembangan kerangka konseptual tahap awal, validasi, dan revisi. Kerangka konseptual yang dihasilkan dari penelitian ini terdiri atas lima komponen: a) belajar statistika menuju akhlak mulia, b) belajar statistika dengan terurut dan bertahap, c) belajar dengan konteks yang bernilai manfaat, d) mengenal istiqra' dalam statistika inferensial, dan e) membangun sikap kritis terhadap informasi kuantitatif. Setiap komponen kemudian dijabarkan dalam bentuk poin-poin yang dapat diterapkan dalam pengembangan materi statistika.
\end{abstract}

Kata Kunci: Integrasi Nilai dan Budaya Keislaman; Kerangka Konseptual; Literasi Statistic; Statistika untuk PTKI. 


\section{Pendahuluan}

Pemahaman dan kemampuan untuk mengaplikasikan ilmu statistika telah menjadi keahlian penting dalam kehidupan masyarakat di era digital saat ini, ${ }^{1}$ sebagai dampak perkembangan teknologi berbasis data. Keahlian statistik pada prinsipnya meliputi dasar-dasar literasi statistik yang biasa digunakan oleh masyarakat umum, ${ }^{2}$ sehingga mereka siap menghadapi informasi kuantitatif dalam kehidupan sehari-hari, ${ }^{3}$ serta mampu berpartisipasi secara aktif dalam debat publik untuk memperoleh hak-hak mereka. ${ }^{4}$

Oleh karena itu, tujuan pembelajaran statistika dasar di perguruan tinggi seharusnya adalah untuk menghasilkan mahasiswa yang terdidik secara statistik (statistically educated), yaitu yang memiliki kemampuan mengembangkan literasi statistik. ${ }^{5}$ Selain itu, mahasiswa juga memerlukan statistika sebagai pengetahuan yang dapat digunakan untuk memahami hasil penelitian kuantitatif di bidang ilmu mereka dan juga untuk dapat melakukan penelitian sebagai bagian dari syarat kelulusan studi mereka. ${ }^{6}$

Rendahnya kemampuan literasi statistik di kalangan pelajar, ${ }^{7}$ bahkan di kalangan guru matematika di Indonesia, ${ }^{8}$ mencerminkan urgensi terhadap

${ }^{1}$ Gail Burrill, "Statistical literacy and quantitative reasoning," dalam Proceedings of the 15th International Conference: Theory and practice-an interface or a great divide, 2019, 4-9; J. Watson, "Curriculum expectations for teaching science and statistics," dalam Proceedings of the International Conference on Teaching Statistics 9, ed. oleh Katie Makar, B. de Sousa, dan Rob Gould (ICOTS 9, Flagstaff, AZ: International Association for Statistical Education (IASE), 2014).

2 Burrill, "Statistical literacy and quantitative reasoning"; Deborah J. Rumsey, "Statistical literacy as a goal for introductory statistics courses," Journal of Statistics Education 10, no. 3 (2002): 6-13; Travis Weiland, "Problematizing statistical literacy: An intersection of critical and statistical literacies," Educational Studies in Mathematics 96, no. 1 (2017): 33-47.

3 Moh Hafiyusholeh, "Literasi Statistik dan Urgensinya Bagi Siswa," Wahana 64, no. 1 (2015): 1-8; Rumsey, "Statistical literacy as a goal for introductory statistics courses."

${ }^{4}$ Lyn D. English dan Jane M. Watson, "Development of probabilistic understanding in fourth grade," Journal for Research in Mathematics Education 47, no. 1 (2016): 28-62; Gillian Lancaster, "Communicating the Value of Statistical Thinking in Research," dalam Data and context in statistics education: Towards an evidence-based society, ed. oleh Chris Reading (The Eighth International Conference on Teaching Statistics, Ljubljana, Sovlenia: International Association for Statistical Education (IASE), 2010).

${ }^{5}$ Martha Aliaga dkk., Guidelines for assessment and instruction in statistics education: College report, vol. 30 (California: American Statistical Association, 2005), http://www.amstat.org/education/gaise/.

6 Illah Sailah dkk., Buku Panduan Kurikulum Pendidikan Tinggi (K-DIKTI) (Jakarta: Direktorat Jenderal Pendidikan Tinggi, 2014).

7 Nikmatul Karimah, "Profil Literasi Statistik Siswa SMA Ditinjau Dari Gaya Kognitif Field dependent Dan Field independent" (UIN Sunan Ampel Surabaya, 2017); Iyam Maryati dan Nanang Priatna, "Analisis Kemampuan Literasi Statistis Siswa Madrasah Tsanawiyah dalam Materi Statistika," Journal of Medives: Journal of Mathematics Education IKIP Veteran Semarang 2, no. 2 (2018): 205-12.

8 Bambang Avip Priatna Martadiputra, "Kajian Tentang Kemampuan Melek Statistis Statistical Literacy , Penalaran Statistis Statistical Reasoning , Dan Berpikir Statistis Statistical Thinking Guru Smp," abmas 83 (2010), http://jurnal.upi.edu/abmas/view/399/kajian- 
pembenahan pembelajaran statistika di tanah air. Pembelajaran statistika yang masih didominasi masalah prosedural dan mengabaikan konsep literasi statistik merupakan penyebab mahasiswa gagal mendapatkan skill yang seharusnya mereka kuasai dari mata kuliah statistika. ${ }^{9}$

Diantara kendala umum yang dihadapi oleh dosen dalam mengajarkan statistika dasar adalah sulitnya memperoleh buku rujukan di Indonesia yang berbasis literasi statistik. Bahan ajar statistika yang telah banyak dikembangkan dalam berbagai penelitian di negara kita umumnya berupa bahan ajar yang berbasis metode pembelajaran tertentu (seperti metode problem-based learning, ${ }^{10}$ generative learning, ${ }^{11}$ dan $\mathrm{CTL}^{12}$ ) atau integrasi dengan teknologi ${ }^{13}$ dan perangkat lunak statistika seperti minitab. ${ }^{14}$ Masih sangat sulit ditemui penelitian yang berfokus pada pengembangan buku atau materi perkuliahan statistika yang berbasis literasi statistik. Buku statistika yang berbasis literasi statistik umumnya berbahasa Inggris dan menggunakan konteks negara-negara barat, yang adakalanya asing dan kurang sesuai dengan konteks Indonesia dan bertentangan dengan nilai-nilai Islam. Sedangkan data dan konteks adalah unsur penting dalam memahami materi statistika. ${ }^{15}$ Sebagai contoh, konteks perjudian yang merupakan perkara terlarang dalam Islam, sangat umum dijadikan konteks acuan ketika membahas masalah probabilitas. Hal seperti ini merupakan salah satu faktor

tentang-kemampuan-melek-statistis--statistical-literacy-,-penalaran-statistis--statisticalreasoning-,-dan-berpikir-statistis--statistical-thinking--guru-smp.

9 J. B. Garfield dan Dani Ben-Zvi, "How students learn statistics revisited: A current review of research on teaching and learning statistics," International Statistical Review 75, no. 3 (2007): 372-96.

10 Ika Krisdiana, "Pengembangan Perangkat Pembelajaran pada Matakuliah Statistika Dasar dengan Metode Problem Based Learning," Jurnal Edukasi Matematika dan Sains 4, no. 1 (2016): 61-65.

11 Yenni Yenni dan Retno Andriyani, "Bahan Ajar Statistika Berbasis Generative Learning untuk Meningkatkan Kemampuan Pemahaman Matematis," Kalamatika: Jurnal Pendidikan Matematika 4, no. 2 (2019): 151-62.

12 Yudhi Hanggara dan Fitrah Amelia, "Pengembangan modul statistik pendidikan berbasis CTL untuk meningkatkan kompetensi mahasiswa universitas riau kepulauan batam," PYTHAGORAS: Jurnal Program Studi Pendidikan Matematika 7, no. 2 (2018): 1-11.

${ }^{13}$ Hamidah Suryani Lukman dan Ana Setiani, "Validitas Bahan Ajar Statistika Terapan Berbasis ICT Terintegrasi Proyek," Edumatika: Jurnal Riset Pendidikan Matematika 1, no. 2 (2018): 36-46.

14 Mira Meilisa dan Lely Kurnia, "Pengembangan bahan ajar statistika elementer menggunakan aplikasi minitab," Sainstek: Jurnal Sains dan Teknologi 10, no. 2 (2019): 6469.

15 Allan Rossman, Beth Chance, dan Elsa Medina, "Some important comparisons between statistics and mathematics, and why teachers should care," dalam Thinking and reasoning with data and chance, ed. oleh Gail Burrill dan P. C. Elliott, vol. 1 (National Council of Teachers of Mathematics, 2006), 323-33. 
kesulitan mahasiswa, terutama yang berasal dari negara-negara Islam, dalam memahami materi statistika. ${ }^{16}$

Di samping itu, fenomena semakin banyaknya perguruan tinggi keislaman di Indonesia yang memiliki fakultas, jurusan, serta program studi sains umum, merefleksikan mandat bagi pengintegrasian sains dan agama dalam pembelajaran. ${ }^{17}$ Mandat ini juga berlaku untuk mata kuliah statistika, ilmu yang selama ini sangat jarang dikaitkan dengan Islam. Oleh karena itu, salah satu urgensi untuk dapat memenuhi mandat tersebut adalah tersedianya buku statistika berbasis literasi statistik yang sesuai untuk digunakan di Perguruan Tinggi Keagamaan Islam (PTKI) di Indonesia.

Beranjak dari permasalahan tersebut, penelitian ini dilakukan sebagai tahap awal untuk menjawab kebutuhan terhadap buku statistika untuk PTKI. Tahap awal ini berupa pengembangan suatu kerangka konseptual yang dapat dijadikan acuan dalam mendesain materi perkuliahan statistika berbasis literasi statistik yang terintegrasi nilai dan budaya keislaman.

Hasil penelitian ini diharapkan dapat memberikan kontribusi signifikan untuk pengembangan literatur penelitian pendidikan statistika, mengingat hingga saat ini masih sangat sulit ditemui penelitian di bidang pendidikan statistika terintegrasi nilai dan budaya keislaman. Pengembangan pembelajaran statistika terintegrasi nilai dan budaya keislaman merupakan bentuk dukungan terhadap upaya integrasi nilai-nilai Islam ke dalam ilmu sains yang menjadi ciri khas PTKI.

\section{Metode}

Penelitian ini menggunakan model penelitian pengembangan yang dikembangkan oleh Borg dan Gall. ${ }^{18}$ Sistem yang dikembangkan dalam penelitian ini berupa kerangka konseptual dengan cara merujuk kepada literatur dan pendapat para pakar yang terkait.

Tahapan yang dilakukan dalam penelitian ini terdiri dari lima tahap (lihat Gambar 1) yang mengacu kepada tiga poin pertama dari langkahlangkah penelitian dan pengembangan. ${ }^{19}$ Sementara langkah lanjutan yang meliputi uji lapangan skala kecil dan revisi, serta uji lapangan skala besar dan produk akhir, akan dilaksanakan pada tahapan penelitian lanjutan. Selain itu, ditetapkan dua arah kajian dalam merancang kerangka konseptual dalam

${ }^{16}$ Khidir M. Abdelbasit, "Learning Statistics in a foreign language," dalam International Encyclopedia of Statistical Science, ed. oleh M. Lovric (Berlin, Heidelberg: Springer, 2011), 729-30.

17 A. Abdusysyakir dan Rosimanidar Rosimanidar, "Model Integrasi Matematika dan AlQuran serta Praktik Pembelajarannya” (Seminar Nasional Integrasi Matematika dan Al-Quran, Bukit Tinggi, Indonesia, 2017).

18 W.R Borg dan M.D Gall, Educational research: An introduction (New York: Longman, 1983).

19 Ibid. 
penelitian ini, yaitu "literasi statistik" dan "konteks keislaman". Arah kajian ini selanjutnya dijadikan sebagai acuan dalam melakukan kajian literatur dan memilih subjek yang terlibat pada tahap validasi.

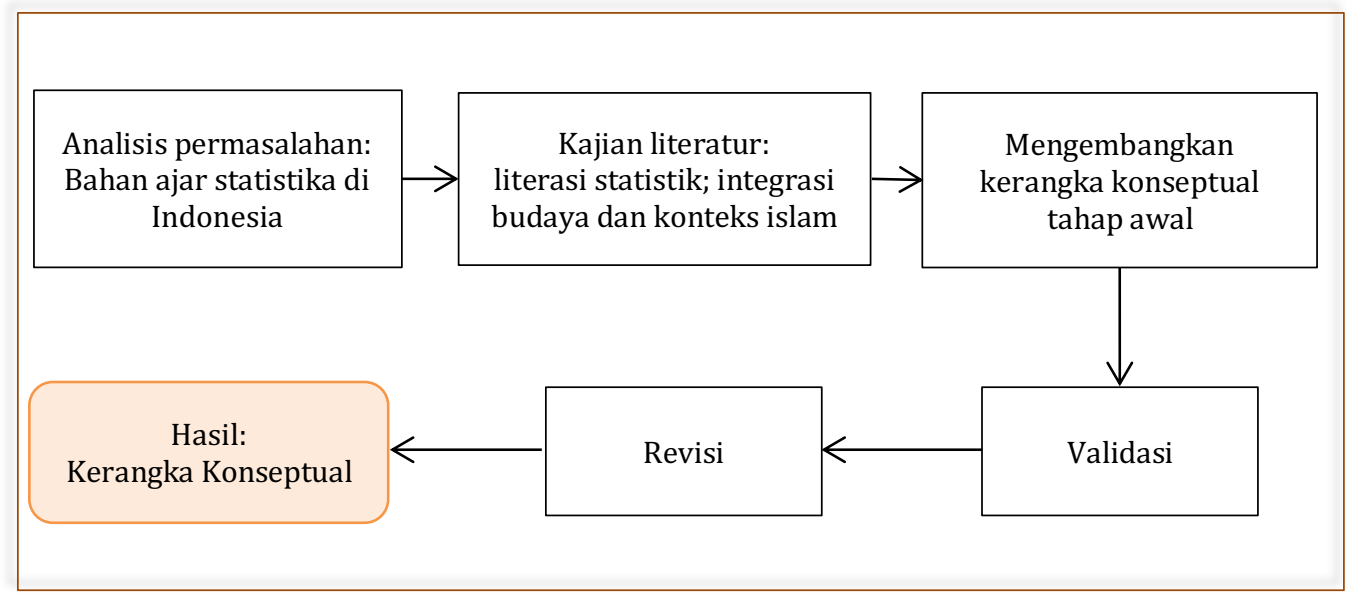

Gambar 1. Tahap Penelitian

\section{Analisis Permasalahan}

Tahap pertama dalam penelitian ini merupakan perwujudan dari analisis produk. Pada tahapan ini dilakukan analisis permasalahan terkait pembelajaran dan materi pembelajaran statistika di tingkat universitas Indonesia. Hal ini dilakukan dengan menelaah standar pembelajaran statistika untuk tingkat universitas dan buku pegangan statistika yang saat ini sering digunakan di Indonesia, terutama di PTKI.

\section{Kajian Literatur}

Tahap kedua meliputi kajian literatur yang akan dijadikan sebagai landasan teori. Tahap ini merupakan langkah kedua penelitian pengembangan, yaitu mengembangkan produk awal. Sesuai dengan arah penelitian yang telah ditetapkan, maka literatur yang dikaji terdiri dari literatur di bidang pendidikan statistika dan literatur tentang integrasi nilai, budaya, dan agama ke dalam pendidikan matematika dan sains. Kajian literatur di bidang pendidikan statistika dilakukan dengan tujuan untuk mengidentifikasi komponen-komponen penting terkait literasi statistik yang diperlukan untuk dimasukkan dalam materi ajar statistika. Sedangkan kajian literatur tentang integrasi nilai, budaya, dan agama ke dalam pendidikan matematika dan sains dilakukan untuk mengidentifikasi komponenkomponen terkait konteks keislaman yang dapat digunakan untuk memaparkan materi ajar statistika. 
3. Pengembangan Kerangka Konseptual Tahap Awal

Pada tahap ketiga, yang juga merupakan bagian dari langkah mengembangkan produk awal, dilakukan penyusunan komponen-komponen yang dianggap penting untuk kerangka analitis berdasarkan hasil dari kajian literatur pada tahap sebelumnya.

\section{Validasi}

Tahap validasi dilakukan dengan tujuan untuk memastikan bahwa tidak ada komponen yang terlewatkan yang seharusnya dimasukkan dalam kerangka konseptual yang telah dikembangkan. Tahap validasi ini dilakukan dengan melibatkan perspektif dari dosen dan mahasiswa statistika di PTKI. Kriteria responden yang dipilih pada tahap ini juga mengikuti dua arah penelitian yang telah ditetapkan seperti yang terlihat pada Tabel 1.

Tabel 1. Kriteria yang Ditetapkan dalam Memilih Responden pada Tahap

Validasi Komponen Kerangka Konseptual

\begin{tabular}{|c|c|c|c|}
\hline Responden & Literasi Statistik & Konteks Keislaman & Jumlah \\
\hline Dosen & $\begin{array}{ll}\text { - } & \text { Memiliki latar } \\
\text { belakang bidang } \\
\text { pendidikan } \\
\text { statistika/matematika, } \\
\text { dan } \\
\text { - } & \text { Memiliki pengalaman } \\
\text { penelitian integrasi } \\
\text { nilai/konteks islam } \\
\text { dan matematika, atau } \\
\text { - } \\
\text { Memiliki pengalaman } \\
\text { mengajar statistika di } \\
\text { PTKI, khususnya di } \\
\text { jurusan non- } \\
\text { matematika }\end{array}$ & $\begin{array}{ll}\text { - } & \text { Memiliki latar } \\
\text { belakang } \\
\text { pendidikan } \\
\text { Islam, dan } \\
\text { - } & \text { Memiliki } \\
\text { pengalaman } \\
\text { menggunakan } \\
\text { statistika sebagai } \\
\text { alat dalam } \\
\text { penelitian, atau } \\
\text { Memiliki } \\
\text { pengalaman } \\
\text { mengajar mata } \\
\text { kuliah metode } \\
\text { penelitian }\end{array}$ & 3 Orang \\
\hline Mahasiswa & $\begin{array}{ll}\text { - } & \text { Berasal dari Jurusan } \\
\text { Matematika, dan } \\
\text { - } \\
\text { Memiliki pengetahuan } \\
\text { keislaman }\end{array}$ & $\begin{array}{ll}\text { - } & \text { Berasal dari } \\
\text { jurusan non- } \\
\text { Statistika/ non- } \\
\text { Matematika, dan } \\
\text { - } \quad \text { Memiliki } \\
\text { pengetahuan } \\
\text { keislaman, dan } \\
\text { - } & \text { Pernah } \\
\text { mengikuti } \\
\text { matakuliah } \\
\text { statistika. }\end{array}$ & $\begin{array}{c}25 \\
\text { Orang } \\
\text { (6 grup } \\
\text { FGD) }\end{array}$ \\
\hline
\end{tabular}


Perspektif responden ditelaah berdasarkan hasil wawancara semiterstruktur yang dilakukan. Sebelum sesi wawancara dimulai, setiap responden terlebih dahulu diminta untuk mengisi kuisioner pertanyaan terbuka (open-ended questions) baik secara online ataupun paper and pencil. Kuesioner ini didesain untuk mengetahui perspektif responden mengenai komponen-komponen penting yang perlu dimasukkan dalam merancang materi statistika yang menekankan konsep literasi statistik berbasis konteks keislaman.

Dengan mempertimbangkan perbedaan kompetensi dari dua tipe responden, maka metode wawancara dilaksanakan secara berbeda untuk dosen dan mahasiswa. Wawancara dengan dosen dilaksanakan secara personal, sementara wawancara dengan mahasiswa dilakukan dengan metode focus group interview. ${ }^{20}$ Setiap wawancara dan diskusi yang berlangsung direkam dan kemudian ditranskripkan untuk analisis lebih lanjut. Walaupun topik diskusi telah ditetapkan sebelumnya sebagai pedoman wawancara, diskusi yang dilakukan dikondisikan sedemikian rupa untuk memastikan setiap peserta memiliki kesempatan untuk mengungkapkan ide dan pemikirannya tanpa dibatasi.

\section{Revisi}

Pada tahap ini dilakukan revisi terhadap komponen yang telah disusun sebelumnya berdasarkan hasil yang diperoleh pada tahap validasi. Hasil dari revisi berupa kerangka konseptual yang akan dapat dibawa pada penelitian lanjutan, yaitu uji lapangan skala besar, untuk menghasilkan kerangka konseptual yang valid dan reliabel.

\section{Hasil dan Diskusi}

Hasil penelitian dan diskusi dipaparkan dengan terlebih dahulu membahas hasil kajian literatur, meliputi literatur terkait literasi statistik dan literatur terkait integrasi nilai dan budaya keislaman dalam pembelajaran matematika. Selanjutnya dibahas perumusan komponen kerangka konseptual tahap awal berdasarkan hasil kajian literatur yang telah dilakukan. Tahap validasi kemudian dipaparkan secara ringkas meliputi hasil analisis respon tertulis dan wawancara dari responden yang terlibat. Untuk memberikan gambaran yang lebih jelas terhadap komponen kerangka konseptual yang telah dirumuskan, maka pemaparan hasil revisi komonen kerangka konseptual diberikan beserta pemaparan contoh penjabaran komponenkomponen tersebut dalam materi statistika. 2000).

${ }^{20}$ Richard A. Krueger dan Mary Anne Casey, Focus groups (Thousand Oaks, CA: Sage, 
1. Kajian Literatur

\subsection{Pengertian Literasi Statistik}

Beragam definisi terhadap "literasi statistik (statistical literacy)" atau melek statistik telah dipaparkan oleh pakar pendidikan statistika dan hingga saat ini belum ada satu kesepakatan khusus mengenai definisi tersebut. Secara umum, beragam definisi tersebut dapat diklasifikasikan menjadi tiga hal, yaitu keahlian (skill) keilmuan, penalaran, atau berpikir kritis.

Definisi literasi statistik yang menekankan pada skil penalaran, kemampuan berpikir kritis dan disposisi dalam mendefinisikan literasi statistik dikemukakan oleh Wallman. ${ }^{21}$ Hal ini mencakup kemampuan seseorang untuk menginterpretasi dan secara kritis mengevaluasi informasi statistik di berbagai jaringan media, dan kemampuan untuk mendiskusikan dan menyampaikan reaksinya terhadap informasi statistik tersebut. ${ }^{22}$

Di sisi lain, keahlian keilmuan menekankan pada isi (content) dari ilmu statistika yang perlu dipahami. Literasi statistik didefinisikan sebagai pemahaman terhadap bahasa dasar dan ide-ide fundamental statistika. ${ }^{23}$ Definisi ini juga diacu sebagai salah satu komponen dari kognisi statistik untuk tujuan pembelajaran. ${ }^{24}$

\subsection{Tujuan Pembelajaran Statistika}

Reformasi dalam pendidikan statistika terjadi sejak akhir 1990-an, dimana para ahli pendidikan di bidang statistika menyerukan pembelajaran statistika untuk lebih berfokus pada literasi, penalaran, dan pemikiran statistik. Seruan ini beranjak dari kekhawatiran terhadap fakta dimana kebanyakan perkuliahan statistika gagal menghasilkan mahasiswa yang terdidik secara statistik. ${ }^{25}$ Moore mencatat beberapa perubahan yang terjadi pada bagian materi (memperbanyak data dan analisis, dan mengurangi topik

${ }^{21}$ Katherine K. Wallman, "Enhancing statistical literacy: Enriching our society," Journal of the American Statistical Association 88, no. 421 (1993): 1-8.

22 Iddo Gal, "Statistical literacy," dalam The challenge of developing statistical literacy, reasoning and thinking (Springer, 2004), 47-78.

${ }^{23}$ R. delMas, "Statistical literacy, reasoning, and thinking: A commentary," Journal of $\begin{array}{llllll}\text { Statistics Education } \quad \text { [online] } & 10, & \text { no. } & 3 & \text { (2002), }\end{array}$ www.amstat.org/publications/jse/v10n3/delmas.html; J. B. Garfield, Robert del Mas, dan Andrew Zieffler, "Assessing important learning outcomes in introductory tertiary statistics courses," Assessment methods in statistical education: An international perspective, 2010, 75-86; Rumsey, "Statistical literacy as a goal for introductory statistics courses."

24 J. B. Garfield dan Christine Franklin, "Assessment of learning, for learning, and as learning in statistics education," dalam Teaching Statistics in School Mathematics-Challenges for Teaching and Teacher Education, ed. oleh Carmen Batanero, Gail Burrill, dan Chris Reading (Dordrecht, The Netherlands: Springer, 2011), 133-45.

25 J. B. Garfield dan Dani Ben-Zvi, Developing students'statistical reasoning: Connecting research and teaching practice (Springer Science \& Business Media, 2008). 
probabilitas), pedagogi (mengurangi ceramah, lebih banyak bentuk pembelajaran aktif), dan teknologi (untuk analisis data dan simulasi). ${ }^{26}$

Hasil yang diharapkan dari mata kuliah statistika universitas adalah mahasiswa memiliki pemahaman konsep, literasi dan pemikiran statistik, dengan mengurangi pembelajaran pada bagian prosedural. Empat tujuan pembelajaran statistika dirumuskan oleh Garfield meliputi: konsep, keahlian, jenis pemikiran dan sikap. ${ }^{27}$

Lebih jauh, Garfield dan Franklin merumuskan tiga kategori yang perlu diperhatikan dalam penilaian kognitif untuk pembelajaran statistik. ${ }^{28}$ Ketiga kategori kognisi statistik ini telah diadaptasi oleh Lei dan Yang untuk menganalisis buku teks, menjadi: pengetahuan dasar statistik (statistical basic knowledge), penalaran statistik (statistical reasoning), dan pemikiran statistik (statistical thinking). ${ }^{29}$ Kognisi statistik ini akan dapat menggambarkan bagaimana pengetahuan statistika direpresentasikan dan bagaimana kompetensi mereka dalam statistika.

Pengetahuan dasar statistik diartikan sebagai memahami dan menggunakan bahasa dasar statistik dan alat (tools) statistik. Jika dijabarkan dalam bahan ajar maka dapat mencakup pemaparan makna atau definisi suatu konsep, membaca informasi dalam tabel/grafik, dan memaparkan prosedur yang berkaitan dengan konsep. Selanjutnya, penalaran statistik meliputi kemampuan untuk bernalar dengan menggunakan ide statistik dan memahami informasi statistik. Dalam bahan ajar, penalaran statistik dapat mencakup sifat-sifat konsep statistik dalam kondisi tertentu, tentang hubungan antara satu konsep dengan konsep yang lain, dan tentang interpretasi. Sementara pemikiran statistik meliputi keahlian untuk mengenali pentingnya menguji hipotesis dan berusaha menjelaskan variabilitas, mengetahui asal sumber data, serta mengaitkan analisis data ke konteks investigasi yang lebih luas. Hal ini dapat dijabarkan dalam bahan ajar secara umum meliputi pemikiran tentang produksi data, evaluasi atau kritik terhadap data atau hasil analisis, dan pemahaman terhadap teori dibalik proses dan metode statistika. ${ }^{30}$

26 David S. Moore, "Statistics among the liberal arts," Journal of the American Statistical Association 93, no. 444 (1998): 1253-59.

27 J. B. Garfield, "How students learn statistics," International Statistical Review/Revue Internationale de Statistique, 1995, 25-34.

${ }^{28}$ Garfield dan Franklin, "Assessment of learning, for learning, and as learning in statistics education."

${ }^{29}$ K. K Lei dan Kai-Lin Yang, "Analysis of statistics content in junior high school mathematics textbooks based on statistical cognition and graph comprehension," Journal of Textbook Research 5, no. 2 (2012): 31-72.

30 Garfield dan Franklin, "Assessment of learning, for learning, and as learning in statistics education"; Khairiani Idris dan Kai-Lin Yang, "Analysis of Tasks in Statistics Textbooks for Future English Teachers Based on Statistical Cognitions," dalam In Pursuit of Quality Mathematics Education for All: Proceedings of the 7th ICMI-East Asia Regional 


\subsection{Rekomendasi Materi Statistika}

Agar pembelajaran statistika di tingkat universitas dapat mencapai tujuan yang diharapkan, Guidelines for Assessment and Instruction in Statistics Education (GAISE) merekomendasikan enam poin penting. Keenam poin tersebut adalah: a) Tekankan literasi statistik dan kembangkan pemikiran statistik; b) Gunakan data yang real; c) Tekankan pemahaman konsep, bukan pengetahuan tentang prosedur semata; d) Terapkan pembelajaran aktif di kelas; e) Gunakan teknologi untuk mengembangkan konsep dan analisis data; dan f) Gunakan penilaian untuk meningkatkan dan mengevaluasi belajar mahasiswa. ${ }^{31}$

Poin-poin rekomendasi tersebut berpotensi untuk diadaptasi ke dalam materi pembelajaran. Namun karena rekomendasi tersebut ditujukan untuk kegiatan pembelajaran statistika di kelas, maka tidak semua poin mungkin relevan untuk materi pembelajaran. Salah satu contohnya adalah rekomendasi keempat tentang pembelajaran aktif yang diwujudkan di dalam kelas.

Rekomendasi yang khusus untuk teks materi statistika di tingkat universitas telah disarankan oleh Idris berdasarkan hasil kajian literatur di bidang pembelajaran statistika. Tiga petunjuk kunci yang disarankan tersebut adalah: a) penggunaan data real; b) konteks yang familiar; dan c) materi interaktif. ${ }^{32}$ Ketiga rekomendasi ini secara umum memiliki keterkaitan dengan enam poin rekomendasi yang diberikan oleh GAISE.

Penggunaan data riil, yang merupakan poin rekomendasi kedua dari GAISE, dianjurkan sebagai aspek penting dalam rangka membantu mahasiswa belajar untuk dapat memformulasikan pertanyaan penelitian dan menggunakan data untuk menjawab pertanyaan-pertanyaan tersebut dengan tepat dengan mengacu pada cara data dihasilkan. ${ }^{33}$ Di sisi lain, kumpulan data buatan (hypothetical data) dapat digunakan untuk mengilustrasikan poin tertentu atau untuk menjelaskan konsep tertentu. ${ }^{34}$ Beragam jenis data yang

Conference on Mathematics Education, 2467-4923 (Print) 2467-4931 (Online) (Philippines: Philippine Council of Mathematics Teacher Educators (MATHTED), Inc., 2015), http://mathted.weebly.com/; Lei dan Yang, "Analysis of statistics content in junior high school mathematics textbooks based on statistical cognition and graph comprehension."

31 Aliaga dkk., Guidelines for assessment and instruction in statistics education: College report.

32 Khairiani Idris, "Teaching and Learning Statistics in College: How Learning Materials Should Be Designed," Journal of Physics: Conference Series 1088 (September 2018): 012032, https://doi.org/10.1088/1742-6596/1088/1/012032.

33 Abdelbasit, "Learning Statistics in a foreign language"; Christine A. Franklin dan J. B. Garfield, "The GAISE project: Developing statistics education guidelines for grades pre-K-12 and college courses," dalam Thinking and reasoning with data and chance: 2006 NCTM yearbook, ed. oleh G. F. Burrill dan P. C. Elliott (Reston, VA: National Council of Teachers of Mathematics, 2006), 345-76.

${ }^{34}$ Aliaga dkk., Guidelines for assessment and instruction in statistics education: College report. 
digunakan ini, yang disebut sebagai makna data oleh Idris dan Yang ${ }^{35}$, dapat digunakan untuk memaparkan suatu konsep statistik. Sebagai contoh, ketika memaparkan konsep tentang rata-rata, data dapat dianggap sebagai bilangan numerik tanpa konteks dengan memfokuskan pada teknik perhitungan. Data sebagai bilangan dalam konteks dapat ditunjukkan dengan memaparkan dan mengaitkan hasil perhitungan dengan konteks dimana data itu berasal. Data sebagai informasi yang dapat diinvestigasi dapat dipaparkan dengan mendorong mahasiswa berpikir tentang alasan mengapa nilai rata-rata digunakan dalam konteks tersebut. Bagaimana makna data ditunjukkan dalam materi ajar merupakan unsur yang penting karena hal itu berhubungan erat dengan penalaran mahasiswa ${ }^{36}$ dan konsepsi mereka terhadap statistika. ${ }^{37}$ Komponen makna data statistik selain mencakup poin rekomendasi kedua dari GAISE, yaitu menggunakan data ril, juga dapat mencakup poin rekomendasi ketiga, tentang menekankan pemahaman konsep atas prosedur. Karena bahan ajar statistik seharusnya tidak hanya fokus pada penyajian makna data sebatas bilangan numerik, tapi juga menyajikan makna data yang lebih tinggi.

Rekomendasi berikutnya terkait konteks yang familiar. Karakteristik data statistik yang tidak dapat dipisahkan dari konteks, ${ }^{38}$ menjadikan jenis konteks yang digunakan sebagai salah satu faktor yang perlu diperhatikan dalam materi pembelajaran. Konteks yang dikenal dapat berupa konteks yang relevan dengan bidang ilmu mahasiswa, selain konteks yang dapat mereka jumpai dalam kehidupan sehari-hari. Penelitian yang dilakukan oleh Hiedemann dan Jones dan Wiberg membuktikan adanya efek positif penggunaan konteks yang relevan dengan bidang ilmu mahasiswa. ${ }^{39}$ Penelitian lainnya oleh Abdelbasit menyimpulkan bahwa penggunaan konteks yang tidak

35 Khairiani Idris dan Kai-Lin Yang, "Development and Validation of an Instrument to Measure Indonesian Pre-service Teachers' Conceptions of Statistics," The Asia-Pacific Education Researcher26, no. 5 (2017): 281-90, https://doi.org/10.1007/s40299-017-0348$\mathrm{z}$.

${ }^{36}$ Arthur Bakker dan K. Gravemeijer, "Learning to reason about distribution," dalam The challenge of developing statistical literacy, reasoning and thinking, ed. oleh Dani Ben-Zvi dan J. B. Garfield (Dordrecht, The Netherlands: Kluwer Academic Publishers, 2004), 147-68, https://doi.org/10.1007/1-4020-2278-6_7.

37 Idris dan Yang, "Development and Validation of an Instrument to Measure Indonesian Pre-service Teachers' Conceptions of Statistics."

${ }^{38}$ Rossman, Chance, dan Medina, "Some important comparisons between statistics and mathematics, and why teachers should care"; Weiland, "Problematizing statistical literacy: An intersection of critical and statistical literacies."

${ }^{39}$ Bridget Hiedemann dan Stacey M. Jones, "Learning statistics at the farmers market? A comparison of academic service learning and case studies in an introductory statistics course," Journal of Statistics Education 18, no. 3 (2010), https://doi.org/10.1080/10691898.2010.11889584; Marie Wiberg, "Teaching statistics in integration with psychology," Journal of Statistics Education 17, no. 1 (2009): 1-16, https://doi.org/10.1080/10691898.2009.11889509. 
dikenal pada buku teks dapat memunculkan problematika bagi mahasiswa. ${ }^{40}$ Akibatnya, ketika mengerjakan latihan yang ada pada buku teks tersebut, mahasiswa cenderung hanya memperhatikan bagian prosedural dan mengabaikan konteks dari permasalahan yang diberikan.

Rekomendasi ketiga adalah tentang materi interaktif. Rekomendasi ini bisa dikaitkan dengan poin rekomendasi kelima dari GAISE, yaitu penggunaan teknologi untuk mengembangkan konsep dan analisis data. Beberapa konsep dasar yang seharusnya dipelajari dalam statistik mencakup ketakpastian, keacakan, kekuatan bukti, signifikansi, dan proses produksi data. ${ }^{41}$ Sementara itu, untuk mempelajari konsep-konsep tersebut diperlukan banyak pengetahuan prosedural seperti kalkulasi matematis dan konstruksi grafik. Karena sifatnya yang dinamis dan visualitatif, penggunaan teknologi dalam pembelajaran statistika telah terbukti dapat mempermudah mahasiswa dalam hal prosedural ${ }^{42}$ dan pemahaman konsep. ${ }^{43}$

Lebih jauh mengenai penggunaan teknologi dalam buku teks, Dunn dkk. (2016) menemukan beberapa buku mengacu pada lebih dari satu jenis software. ${ }^{44}$ Di samping itu, secara umum ada 5 jenis pendekatan yang digunakan oleh buku teks dalam menggunakan software: 1) menyusun instruksi singkat tentang cara menerapkan teknik yang dibahas dalam beberapa paket software yang berbeda, yang biasanya diletakkan di akhir setiap bab; 2) menampilkan output dari beberapa paket software dalam permasalahan yang dipaparkan, dan meminta interpretasi, tanpa memberikan instruksi tentang penggunaan software-software tersebut; 3) menampilkan output dari software, tetapi tampilan outputnya sudah dimanipulasi dan sumbernya tidak disebutkan; 4) menyediakan file data elektronik baik dalam buku teks ataupun dalam halaman web terkait; dan 5) menyediakan beberapa pendekatan analisis yang berbeda tergantung pada ada tidaknya data dan teknologi. Selain jenis paket software yang digunakan dan pendekatan yang digunakan dalam menampilkan software tersebut dalam buku teks, penggunaan teknologi juga perlu mempertimbangkan sejauh mana teknologi tersebut berguna untuk mengembangkan konsep statistika.

${ }^{40}$ Abdelbasit, "Learning Statistics in a foreign language."

${ }^{41}$ Dani Ben-Zvi, Arthur Bakker, dan Katie Makar, "Learning to reason from samples," Educational Studies in Mathematics 88, no. 3 (2015): 291-303.

42 Pei-Yu Wang, Brandon K. Vaughn, dan Min Liu, "The impact of animation interactivity on novices' learning of introductory statistics," Computers \& Education 56, no. 1 (2011): 300311.

43 Maria Meletiou-Mavrotheris, "Technological Tools in the Introductory Statistics Classroom: Effects on Student Understanding of Inferential Statistics," International Journal of Computers for Mathematical Learning 8, no. 3 (1 Oktober 2003): 265-97, https://doi.org/10.1023/B:IJC0.0000021794.08422.65.

44 Peter K. Dunn dkk., "Introductory Statistics Textbooks and the GAISE Recommendations," The American Statistician 0, no. ja (28 Oktober 2016): 0-0, https://doi.org/10.1080/00031305.2016.1251972. 


\subsection{Integrasi Nilai dan Budaya Keislaman}

Pengintegrasian nilai dan budaya islam telah dikenal dalam berbagai ilmu umum, seperti sains, ${ }^{45}$ bimbingan konseling, ${ }^{46}$ termasuk matematika. ${ }^{47}$ Nilai-nilai mulia yang diajarkan dalam Islam secara komprehensif dapat diintegrasikan dan ditekankan dalam pembelajaran matematika, terutama bagi pelajar sekolah. Selain itu, karakteristik matematika bersesuaian juga dengan nilai-nilai akhlak Islam, seperti sabar, jujur, konsisten, dan lain-lain. ${ }^{48}$ Keajaiban susunan angka numerik yang disebutkan dalam al-Quran juga menjadi bahan kajian menarik yang dapat diintegrasikan dalam pembelajaran matematika sekolah. ${ }^{49}$ Materi-materi matematika yang dibahas dalam penelitian tersebut mencakup aljabar, geometri, pecahan, dan lain-lain.

Sementara itu, hingga saat ini belum ditemukan sebuah penelitian tentang integrasi Islam dan matematika yang mengkhususkan pada materi statistika, baik untuk siswa sekolah maupun untuk mahasiswa perguruan tinggi. Secara umum, statistika memiliki beberapa karakteristik yang berlawanan dengan matematika. Di antara perbedaannya adalah matematika lebih bersifat rasional, objektif, dan pasti, sedangkan suatu hasil dari analisis statistika bersifat takpasti, berdasarkan pada opini, aproksimasi, dan inferensinya tergantung pada konteks permasalahan. ${ }^{50}$

Oleh karena itu, penulis berusaha menelaah literatur dalam bidang keislaman untuk menemukan adanya nilai-nilai dan konteks budaya keislaman yang dapat dikaitkan dengan statistika maupun pembelajaran statistika. Hasil dari sintesis literatur tersebut kemudian dipaparkan berdasarkan topik dalam konsep-konsep atau pembelajaran statistika.

${ }^{45}$ A. Rusdiana, "Integrasi pendidikan agama islam dengan sains dan teknologi," Istek 8, no. 2 (2014): 123-43.

46 Yuni Novitasari dan Muhammad Nur, "Bimbingan dan konseling belajar (akademik) dalam perspektif Islam," Indonesian Journal of Educational Counseling 1, no. 1 (2017): 53-78.

47 Abdusysyakir dan Rosimanidar, "Model Integrasi Matematika dan Al-Quran serta Praktik Pembelajarannya"; Masduki Masduki, R. P. Khotimah, dan S. Sutarni, "Islamic values in mathematics learning" (International Conference on Research, Implementation and Education of Mathematics and Science, Yogyakarta, Indonesia, 2014), 359-69.

${ }^{48}$ Masduki, Khotimah, dan Sutarni, "Islamic values in mathematics learning."

49 A. Kurniati, "Mengenalkan matematika terintegrasi islam kepada anak sejak dini," Suska Journal of Mathematics Education 1, no. 1 (2015): 1-8; Mahdalena Mahdalena, Pembelajaran Matematika dan Konsepnya dalam Alquran (Lhokseumawe, Aceh: Unimal Press, 2017).

50 Alan Graham, Developing Thinking in Statistics (London: Paul Chapman Publising, 2006); Rossman, Chance, dan Medina, "Some important comparisons between statistics and mathematics, and why teachers should care." 


\subsection{Nilai dan Budaya Islam tentang Belajar}

Dalam pandangan agama Islam, belajar merupakan suatu bentuk ibadah untuk mendekatkan diri (taqarrub) kepada Allah, sehingga harus diniatkan untuk mencari keridhaan Allah. ${ }^{51}$ Imam Al-Ghazali menekankan bahwa belajar merupakan suatu proses yang mengarah pada perubahan tingkah laku menuju akhlak yang mulia. Secara lebih spesifik beliau menyatakan bahwa belajar merupakan proses jiwa, menuntut konsentrasi, harus didasari sikap tawadhu' dan dilakukan secara bertahap. Selain itu, orang bertukar pendapat haruslah memiliki dasar yang kuat, mengetahui nilai dan tujuan ilmu yang sedang dipelajari dan tujuannya adalah membentuk akhlak yang mulia. ${ }^{52}$

Pengintegrasian nilai dan budaya Islam tentang belajar ini dapat dikelompokkan dalam jenis pengintegrasian proses yang dikemukakan oleh Muhajir, yaitu selama pembelajaran berlangsung tidak ada sesuatu hal yang berlawanan dengan ajaran Islam. ${ }^{53}$

\subsection{Nilai dan Budaya Islam tentang Metode Penarikan Kesimpulan}

Para ulama dalam menyimpulkan suatu hukum yang tidak memiliki landasan yang tertulis jelas di dalam al-Quran atau al-Hadist, adakalanya menggunakan beberapa metode, diantaranya adalah metode Istiqra' (induksi). ${ }^{54}$ Istiqra' diartikan dengan menarik kesimpulan umum berdasarkan karakterisik satuan-satuannya ${ }^{55}$, atau sebuah metode pengambilan kesimpulan umum yang dihasilkan oleh fakta-fakta khusus yang digunakan oleh ahli-ahli Fiqh untuk menetapkan suatu hukum. ${ }^{56}$ Prinsip pengambilan keputusan seperti ini dikenal juga dengan istilah penalaran induktif dalam metodologi penelitian ${ }^{57}$ yang dipakai dalam statistika inferensial.

Dalam penerapannya, istiqra' dibagi menjadi dua macam, yaitu penelitian secara menyeluruh (Tamm) dan penelitian yang hanya dilakukan pada sebagian besar permasalahan (Naqish). Sebagai contoh, Imam Syafi'i menggunakan metode istiqra' naqish dalam menetapkan batasan-batasan haid dan nifas, dengan mendasarkan pada kebiasaan (urf) di kalangan wanita Arab. Jika dikaitkan dengan istilah dalam statistika, maka tamm bisa

${ }^{51}$ Abdul Halim Mahmood, Hal Ihwal Tasawwuf, dari al Munqidz Min al Dlalâl, trans. oleh Abu Bakar Basymeleh (Jakarta: Darul Ihya', 1994).

52 Al-Ghazali, Ihyâ' Ulûmuddîn, Juz 1, t.t.

53 Zubaidah Amir, "Integrasi nilai pendidikan islam dalam pendidikan umum sebagairevitalisasi pendidikan islam," Potensia Jurnal Kependidikan Islam 12, no. 1 (2013): 122.

54 Taha Jabir Al-Awani, Metodologi Hukum Islam Kontemporer(Yogyakarta, Indonesia: UII Press, 2001).

55 Hasan Mu'arif Ambary, "Istiqra'," dalam Suplemen Ensiklopedi Islam, ed. oleh Abdul Aziz Dahlan (Jakarta: Jakarta: PT Ikhtiar Baru Van Hoeve, 1996).

${ }^{56}$ Al-Awani, Metodologi Hukum Islam Kontemporer.

${ }^{57}$ Donald Ary dkk., Introduction to Research in Education, 8 ed. (California: Wadsworth, 2010). 
diserupakan dengan penerapan penalaran induktif sempurna ${ }^{58}$ atau sebagai metode sensus, dimana penelitian dilakukan pada setiap unsur sampel yang ada. Sementara itu, naqish merupakan jenis penalaran induktif tidak sempurna ${ }^{59}$ yang diterapkan dalam statistika inferensial, yaitu mengambil beberapa sampel dari populasi untuk ditarik sebuah kesimpulan yang bisa digeneralisasikan untuk seluruh populasi.

Hukum yang dihasilkan oleh Istiqra' tamm adalah qat'i (pasti, tidak bisa dibantah) dan hukum dari kesimpulan yang dihasilkan Istiqra' naqish adalah zanni (kemungkinan besar benar), sebagaimana hukum yang terdapat pada kitab-kitab fiqh pada umumnya. Demikian juga dalam statistika inferensial dikenal istilah error pengambilan sampel (sampling error atau margin of error). ${ }^{60} \mathrm{Hal}$ ini menunjukkan bahwa prinsip-prinsip metode penelitian dalam statistika, terkait aturan pengambilan sampel, pengambilan keputusan, serta bagaimana menyikapi kesimpulan yang dihasilkan dari suatu penelitian telah lama dikenal dan diterapkan oleh para ulama dalam bidang fiqih.

Nilai dan konteks islam tentang metode penarikan kesimpulan ini dapat digolongkan dalam jenis pengintegrasian materi pelajaran, ${ }^{61}$ dimana dilakukan pengintegrasian konsep atau ajaran Islam ke dalam materi (konsep) statistika yang sedang diajarkan.

\subsection{Nilai dan Konteks Islam tentang Data}

Dalam al-Quran dan beberapa hadis dapat ditemui beberapa jenis konteks matematika. Misalnya dalam QS. An-Nisa' Ayat 11 dan 176 yang membahas tentang pembagian harta warisan. Dalam konteks dua ayat tersebut, matematika ditampilkan sebagai konsep dan teknik yang berguna dalam kehidupan manusia serta dalam beribadah kepada Allah SWT. Sementara itu, data yang digunakan dalam statistika merupakan data yang juga memiliki konteks tertentu. Karena itu, pemilihan konteks yang melatarbelakangi data yang digunakan dalam materi dan pembelajaran statistika semestinya lebih memperhatikan manfaat dalam kehidupan manusia dan juga dalam beribadah.

58 Ibid.

59 Ibid.

60 Theodore Coladarci dkk., Fundamentals of Statistical Reasoning in Education (N): John Wiley \& Sons, Inc., 2004).

${ }^{61} \mathrm{Amir}$, "Integrasi nilai pendidikan islam dalam pendidikan umum sebagai revitalisasi pendidikan islam." 
Pengintegrasian nilai dan budaya islam tentang data dapat dikategorikan dalam jenis pengintegrasian materi pelajaran dan juga pengintegrasian dalam memilih media pengajaran. Dalam hal ini merupakan pemilihan konteks yang bersesuaian dengan Islam.

1.8. Nilai dan Konteks Islam tentang Pengumpulan dan Penyajian Data

Dalam bukunya, Ketika Kyai Mengajar Matematika, Abdusysyakir62 menjabarkan bagaimana al-Quran membicarakan masalah yang terkait dengan pengumpulan data, yaitu mencatat atau membukukan data. Salah satu contohnya ada dalam Surat al-Qamar ayat 52:63

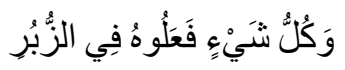

Artinya: Dan segala sesuatu yang telah mereka perbuat tercatat dalam buku-buku catatan. (Al-Qamar: 52).

Selain itu, beliau juga memaparkan bagaimana keajaiban statistik terdapat dalam al-Quran terkait "ketelitian dan keseimbangan dalam jumlah penyebutan suatu kata ketika dikaitkan dengan sinonim, antonim, akibat, penyebab, atau bahkan dengan realitas kehidupan sehari-hari."64

Kedua fakta tentang statistika dalam al-Quran yang dipaparkan tersebut dapat dijadikan sebagai landasan untuk memberikan pemahaman kepada mahasiswa bahwa aktifitas pengumpulan data dan penyajian data telah diperkenalkan dalam al-Quran. Kemudian dapat diperkuat pula dengan menambahkan pentingnya proses pengumpulan data yang benar dan juga menyajikan data dengan menarik dan mudah dipahami oleh orang lain.

\section{Perumusan Komponen Kerangka Konseptual Tahap Awal}

Berdasarkan hasil kajian literatur, dirumuskan lima komponen yang tercakup dalam kerangka konseptual, yaitu: 1) akhlak mulia sebagai tujuan belajar, 2) belajar dengan terurut dan bertahap, 3) penggunaan konteks permasalahan yang bernilai manfaat, 4) pengenalan metode inferensial istiqra', dan 5) membangun sikap kritis terhadap informasi kuantitatif. Komponen-komponen tersebut dijabarkan sebagai berikut:

${ }^{62}$ A. Abdusysyakir, Ketika kyai mengajar matematika (Malang, Indonesia: UIN-Malang Press, 2007).

63 Kementrian Agama RI, al-Quran dan Terjemahan (Jakarta: Al-Fadhilah, 2016).

${ }^{64}$ Abdusysyakir, Ketika kyai mengajar matematika, 149. 


\subsection{Belajar Statistika Menuju Akhlak Mulia}

Pada dasarnya tujuan mempelajari statistika adalah untuk belajar dari data. ${ }^{65}$ Belajar dari data bermakna kita harus melakukan sesuatu yang tidak sekedar menghitung dan membuat grafik, tetapi juga memahami konteks yang menjadi latar belakang data. ${ }^{66}$ Sementara itu, belajar dalam Islam adalah suatu bentuk ibadah untuk mendekatkan diri pada Allah ${ }^{67}$, serta suatu proses yang mengarah pada perubahan tingkah laku menuju akhlak yang mulia. ${ }^{68}$ Dengan demikian tujuan utama belajar statistika yang diintegrasikan dengan nilai dan budaya keislaman dapat dirumuskan sebagai belajar untuk memahami data dan konteksnya dengan memperhatikan akhlak dan adab yang diajarkan oleh Islam. Sehingga pemahaman yang diperoleh tersebut dapat dibarengi dengan perbaikan pada sikap dalam menilai dan menyikapi suatu informasi dan permasalahan dalam kehidupan.

Dengan memaparkan tujuan pembelajaran statistika secara umum beserta tujuan-tujuan khusus dalam pembahasan setiap topik, mahasiswa diharapkan akan dapat memahami ke arah mana materi yang disajikan di buku atau bahan ajar tersebut dimaksudkan. Sebagai contoh, tujuan mempelajari topik tentang distribusi data yang diintegrasikan dengan penanaman akhlak mulia adalah mahasiswa mengetahui tata cara menilai dan memeriksa sekumpulan data (kognisi statistik: pengetahuan dasar), sehingga ketika dihadapkan pada suatu informasi kuantitatif, mahasiswa mampu melakukan interpretasi, menilai (kognisi statistik: penalaran statistik), menyampaikan pendapat dan kritik terhadap informasi tersebut (kognisi statistik: pemikiran statistik) dengan menggunakan kata-kata yang ilmiah dan santun (literasi statistik dan akhlak mulia), mampu menghargai perbedaan pendapat (akhlak mulia), dan memiliki sikap dan pemikiran terbuka untuk mendapatkan kebenaran (literasi statistik dan akhlak mulia).

\subsection{Belajar Statistika dengan Terurut dan Bertahap}

Konsep-konsep dalam statistika memiliki keterkaitan antara satu dengan yang lain yang dilatarbelakangi oleh suatu ide besar (big idea). ${ }^{69}$ Sementara itu, Al-Ghazali ${ }^{70}$ menyatakan bahwa proses belajar menuntut konsentrasi dan sikap tawadhu sehingga semestinya dilakukan secara

${ }^{65}$ David S. Moore, George P. McCabe, dan Bruce A Craig, Introduction to the Practice of Statistics, 8th edition (New York: W. H. Freeman, 2014).

${ }^{66}$ Rossman, Chance, dan Medina, "Some important comparisons between statistics and mathematics, and why teachers should care."

${ }^{67}$ Mahmood, Hal Ihwal Tasawwuf, dari al Munqidz Min al Dlalâl.

${ }^{68}$ Al-Ghazali, Ihyâ' Ulûmuddîn.

${ }^{69}$ J. B. Garfield dan Dani Ben-Zvi, "Research on Statistical Literacy, Reasoning, and Thinking: Issues, Challenges, and Implications," dalam The Challenge of Developing Statistical Literacy, Reasoning and Thinking, ed. oleh Dani Ben-Zvi dan Joan Garfield (Springer Netherlands, 2004), 397-409, http://link.springer.com/chapter/10.1007/1-4020-2278$6 \_17$.

${ }^{70}$ Al-Ghazali, Ihyâ' Ulûmuddîn. 
bertahap. Dengan demikian, pemaparan materi statistika yang diintegrasikan dengan nilai dan budaya keislaman semestinya dilakukan secara tertata dan tersusun sistematis. Hal ini agar tidak terkesan bahwa antara satu konsep dengan konsep lainnya saling terpisah. Penekanan terhadap ide besar yang melatarbelakangi konsep yang dipelajari juga perlu dilakukan untuk memberi gambaran kepada mahasiswa akan keterkaitan tersebut. Misalnya, konsepkonsep yang perlu dipelajari untuk topik distribusi data mencakup pemahaman dasar tentang data dan jenis-jenis data, penyajian data dalam bentuk grafik, perhitungan nilai-nilai statistik, dan dilanjutkan dengan mempelajari transisi nilai-nilai statistik tersebut ke dalam model statistik, serta menggunakan kurva kepadatan untuk mendeskripsikan data. Maka pada pembahasan salah satu konsep perlu dipaparkan juga keterkaitannya dengan konsep-konsep sebelumnya dan konsep-konsep yang akan dipelajari berikutnya, serta keterkaitan dengan ide besar yang menaungi konsep tersebut. Salah satu cara yang dapat digunakan untuk memperlihatkan keterkaitan tersebut misalnya dengan menampilkan diagram peta konsep yang dapat dirujuk di pembahasan setiap konsep. Dengan melakukan hal ini diharapkan mahasiswa dapat memiliki gambaran tentang tahapan dan arah pembelajaran yang dipaparkan dalam buku atau bahan ajar tersebut.

\subsection{Belajar dengan Konteks yang Bernilai Manfaat}

Pemecahan masalah berkaitan dengan data statistik memerlukan pemahaman terhadap konteks yang melatarbelakangi data tersebut. ${ }^{71}$ Sementara dalam ajaran Islam, apa yang dipelajari seharusnya adalah sesuatu yang dapat mendatangkan manfaat, baik dalam ibadah maupun dalam kehidupan sehari-hari. Oleh karena itu, untuk pembelajaran statistika yang diintegrasikan dengan nilai dan budaya keislaman, maka perlu diperhatikan pemilihan konteks yang melatarbelakangi data yang digunakan. Konteks permasalahan yang disajikan haruslah yang tidak bertentangan dengan nilai dan ajaran Islam. Konteks-konteks permasalahan yang menekankan kebermanfaatan bagi kehidupan manusia serta kebermanfaatan dalam melakukan ibadah lebih diutamakan.

Pemilihan konteks yang demikian misalnya dapat dilakukan ketika membahas istilah-istilah yang digunakan dalam statistika, dengan memberikan ilustrasi kejadian yang berkaitan dengan aktifitas ibadah, atau aktifitas-aktifitas lainnya yang berkaitan dengan kehidupan seorang muslim. Salah satu contoh, ketika memperkenalkan istilah "variabilitas" maka dapat diberikan ilustrasi beragamnya usia orang-orang yang mengikuti ibadah shalat idul fitri di suatu masjid. Dengan melakukan hal ini, mahasiswa dapat

${ }^{71}$ Rossman, Chance, dan Medina, "Some important comparisons between statistics and mathematics, and why teachers should care." 
memberikan kesan kepada mahasiswa bahwa statistika merupakan hal yang dekat dengan kehidupan mereka.

\subsection{Mengenal Istiqra' dalam Statistika Inferensial}

Prinsip penalaran induktif berlaku dalam statistika inferensial, dimana seseorang dapat mengambil kesimpulan tentang suatu populasi berdasarkan pada karakteristik sampel yang diambil dari populasi tersebut. ${ }^{72}$ Prinsip tersebut juga telah diterapkan oleh para ulama fikih dalam menyimpulkan suatu hukum yang tidak terdapat nash-nya langsung dalam al-Quran dan alHadis, yang dikenal dengan metode istiqra.733 Dengan demikian, pada pengenalan materi statistika inferensial yang diintegrasikan dengan nilai dan budaya keislaman, dapat diselipkan contoh permasalahan tentang metode istiqra'yang sudah dikenal dalam sejarah keilmuan Islam.

Lebih jauh, pengenalan terhadap istilah istiqra'tamm dan istiqra'naqish dapat dikaitkan dengan istilah metode sensus dan sampling, serta pembahasan konsep sampling error pada topik statistika inferensial. Dengan memberikan contoh permasalahan dan penelitian yang dilakukan para ulama yang menerapkan metode-metode ini, maka diharapkan dapat memberikan gambaran kepada mahasiswa tentang dekatnya ilmu statistika dengan keilmuan islam.

\subsection{Membangun Sikap Kritis terhadap Informasi Kuantitatif}

Salah satu sikap yang perlu dibangun pada mahasiswa statistika adalah sikap kritis terhadap analisis dan kesimpulan dari penelitian, yang merupakan unsur dari pemikiran statistik. ${ }^{74}$ Untuk memiliki sikap kritis ini diperlukan pengetahuan tentang error pengambilan sampel (sampling error atau margin of error), yang menunjukkan besarnya kemungkinan kesalahan yang dilakukan ketika mengambil sampel sehingga berdampak pada kesimpulan yang dihasilkan. ${ }^{75}$ Serupa dengan hal tersebut, dalam menyikapi suatu ketentuan hukum yang dihasilkan oleh metode istiqra' seseorang perlu mengetahui jenis istiqra'yang digunakan. Hukum yang dihasilkan dari Istiqra' tamm adalah qat'i (pasti), sehingga seseorang harus meyakininya tanpa bantahan. Sementara hukum dari kesimpulan yang dihasilkan Istiqra' naqish adalah zanni, yaitu kemungkinan besar bernilai benar. Dalam pembelajaran statistika yang diintegrasikan dengan nilai dan budaya keislaman, dapat ditekankan mengenai sikap kritis terhadap hasil penelitian, sebagaimana

${ }^{72}$ Coladarci dkk., Fundamentals of Statistical Reasoning in Education.

${ }^{73}$ Al-Awani, Metodologi Hukum Islam Kontemporer.

${ }^{74}$ Idris dan Yang, "Development and Validation of an Instrument to Measure Indonesian Pre-service Teachers' Conceptions of Statistics"; Maxine Pfannkuch dan Chris Wild, "Towards an understanding of statistical thinking," dalam The challenge of developing statistical literacy, reasoning and thinking, ed. oleh Dani Ben-Zvi dan J. B. Garfield (Netherland: Springer, 2004), $17-46$.

${ }^{75}$ Coladarci dkk., Fundamentals of Statistical Reasoning in Education. 
sikap kritisnya para ulama dahulu ketika berhadapan dengan perbedaan ketentuan hukum.

2. Validasi Komponen Kerangka Konseptual

Validasi dilakukan dengan tujuan untuk memastikan tidak ada komponen penting yang terlewatkan dalam perumusan kerangka konsepatual. Pada tahap ini, komponen-komponen yang dirumuskan dalam kerangka konseptual tahap awal divalidasi dengan melibatkan responden yang terdiri dari 3 orang dosen dan 25 orang mahasiswa. Proses dan hasil validasi ini diuraikan dengan mendetil dalam artikel lain yang telah dipublikasi sebelumnya. ${ }^{76}$

Secara umum, seluruh responden menyatakan bahwa mereka mendukung upaya integrasi nilai-nilai budaya dan keislaman dalam pembelajaran statistika. Nilai-nilai budaya dan keislaman yang memungkinkan untuk diintegrasikan ke dalam pembelajaran statistika sangat banyak, terutama terkait karakter positif yang bisa ditanamkan pada diri mahasiswa, seperti kesopanan, interaksi antar sesama dan saling menghargai. Hal ini dapat dilihat dari respon dua responden berikut:

"... sebagai contoh nilai budaya kerjasama dan kebersamaan serta nilai agama kejujuran dapat diintegrasikan dalam materi pengumpulan data dan pengolahan data statistika."

"... nilai kebudayaan dan keislaman sangat penting dalam mempelajari statistika seperti kesopanan dalam interaksi sesama, saling menghargai baik antar mahasiswa maupun dengan dosen."

Selain itu, salah seorang dosen juga mengemukakan beberapa aspek lain dari materi statistika yang memungkinkan untuk diintegrasikan ke dalam pembelajaran statistika, seperti aspek konsistensi, keteraturan dan keindahan yang dapat disesuaikan dengan nilai budaya dan keislaman.

"... kekonsistenan dalam penggunaan simbol, keindahan penyajian dan tata letak, dan penggunaan gambar atau contoh yang selaras dengan nilai budaya dan agama."

Beberapa orang mahasiswa menyebutkan contoh-contoh konteks dimana nilai budaya dan keislaman yang mungkin diintegrasikan ke dalam pembelajaran statistika, misalnya konteks budaya tari saman.

"Tari saman merupakan budaya yang dapat diintegrasikan ke dalam statistika bagian penyajian data. Misalnya anggota tari saman berjumlah 100 orang, maka bisa dibuat dalam tabel berupa warna baju dan frekuensinya. Contohnya baju hijau 25 orang, baju merah 36 dan seterusnya."

${ }^{76}$ Khairiani Idris, "Literasi Statistik Berbasis Konteks Budaya dan Keislaman: Perspektif Dosen dan Mahasiswa PTKI," dalam Prosiding SI MaNIs, ed. oleh A. Abdusysyakir, vol. 3 (Seminar Nasional Integrasi Matematika dan Nilai-Nilai Islami, Malang, Indonesia: Jurusan Matematika UIN Maulana Malik Ibrahim, 2020), [357-362]. 
Dalam pembahasan tentang pengintegrasian dalam komponen literasi statistik, makna data, dan teknologi, hampir seluruh responden memberikan beberapa contoh nilai dan konteks budaya dan keislaman yang dapat diintegrasikan ke dalam topik tertentu dalam pembelajaran statistika, seperti shalat, haji, dan pengajian, sedangkan konteks budaya meliputi adat masyarakat seperti maulid, walimah, dan takziyah.

Dari hasil validasi diperoleh bahwa bentuk integrasi konteks keislaman dalam pembelajaran statistika dapat berupa penanaman karakter positif dalam diri mahasiswa. Selain itu, perlu diberikan juga berbagai contoh konteks nilai-nilai budaya dan keislaman yang memungkinkan untuk diintegrasikan ke dalam pembelajaran statistika.

\section{Komponen Kerangka Konseptual dan Penjabarannya dalam Materi}

Statistika

Revisi terhadap komponen kerangka konseptual dilakukan dengan memastikan bahwa kedua unsur yang didapati dari hasil validasi tercakup dalam komponen kerangka konseptual yang direvisi. Unsur pertama berupa penanaman karakter positif tercakup dalam komponen pertama (belajar statistika menuju akhlak mulia. Unsur kedua, yaitu contoh konteks nilai budaya dan keislaman dipastikan dapat tercakup dalam komponen ketiga (belajar dengan konteks yang bernilai manfaat) dan komponen keempat (mengenal istiqra'dalam statistika inferensial).

Komponen-komponen yang telah dijabarkan seperti yang terlihat pada Gambar 2 disajikan dengan paparan contoh poin-poin yang dapat dicakup dalam materi pembelajaran untuk setiap unsur literasi statistik terkait dengan nilai budaya dan keislaman. Poin-poin contoh ini dapat dikembangkan lagi dengan lebih mendetail ketika diaplikasikan dalam merancang materi pembelajaran statistika. Penjabaran poin-poin ini tidak dimaksudkan untuk membatasi kreatifitas dosen yang ingin merancang materi pembelajaran, tetapi hanya sebagai panduan awal. Dengan kreatifitas dosen, pengembangan penjabaran setiap poin kemungkinan dapat berbeda. Selama penjabaran tersebut tidak menyalahi prinsip awal rancangan pembelajaran, yaitu meliputi tiga unsur literasi statistik dan lima unsur nilai dan budaya keislaman, maka pengembangan yang dilakukan dapat dijadikan sebagai penyempurnaan kerangka konseptual ini. Sebagai contoh, pada kolom konteks bermanfaat, peneliti merumuskan poin yang sama untuk setiap unsur literasi statistik, yaitu "Selalu menyajikan contoh konteks data yang memiliki nilai kebermanfaatan dan tidak bertentangan dengan Islam." Dengan kreatifitas dan berdasarkan pada pengalaman dosen statistika, poin ini dapat dikembangkan lagi dengan lebih mendetil untuk setiap pembahasan konsep tertentu dalam materi pembelajaran statistika. 


\section{Tujuan Pembelajaran: Akhlak Mulia}

- Menyebutkan tujuan mempelajari suatu konsep, sifat dan hubungan antar konsep, dengan menekankan sifat jujur dalam interpretasi data tanpa menyembunyikan fakta.

- Menjelaskan tujuan mengetahui proses produksi data dan teori-teorinya, membiasakan evaluasi dan kritik dengan berlandaskan pengetahuan dan menghargai adanya pendapat atau perspektif yang berbeda terhadap data.

- Menjelaskan tujuan menggunakan software statistika sebagai alat untuk mempermudah pembelajaran dan pemahaman konsep.

\section{Penyajian Materi Terurut dan Bertahap}

- Menyajikan konsep, menjelaskan sifat-sifat dan hubungan antar konsep yang tertata dan bertahap sesuai dengan ide besar yang menaungi konsep-konsep tersebut.

- Menjelaskan tahapan produksi data dan metode analisis statistik yang tercakup dalam suatu penelitian, serta kaitannya dengan kesimpulan yang akan diperoleh.

- Menjelaskan langkah-langkah pengoperasian teknologi dengan terurut dan bertahap sehingga mudah diikuti

- Menyajikan makna data yang sesuai dengan tujuan pembahasan secara bertahap.

Konteks

- Selalu menyajikan contoh konteks yang memiliki nilai kebermanfaatan dan tidak bertentangan dengan Islam

\section{Istiqra'}

- Memperkenalkan istilah istiqra' sebagai salah satu bagian dari statistika inferensial, serta dua jenis metodenya.

- Menjelaskan interpretasi hasil penelitian atau kesimpulan yang diperoleh dari metode istiqa', serta kelemahan dan kelebihan dari dua jenis metodenya.

- Memaparkan cara mengevaluasi dan mengkritisi kesesuaian penggunaan metode istiqra' dalam beberapa contoh kasus dengan menggunakan bahasa yang ilmiah dan santun.

- Menelaah kemungkinan persamaan dan perbedaan metode statistika inferensial dengan metode istiqra'

- Menyajikan contoh pengambilan data dalam metode istiqra'.

\section{Kritis}

- Mendorong mahasiswa membaca dan mengomentari informasi yang ditampilkan dengan berlandaskan pengetahuan tentang konteks permasalahan.

- Menjelaskan cara interpretasi data dengan merujuk pada pemahaman tentang konsep, serta kelebihan dan kekurangan konsep tersebut.

- Menjelaskan cara mengomentari dan mengkritisi data yang dihasilkan berdasarkan konteks permasalahan yang melatarbelakangi data tersebut.

- Mengevaluasi penggunaan teknologi untuk membantu pembelajaran.

- Membandingkan penggunaan beberapa jenis teknologi yang berbeda.

Gambar 2. Contoh Penjabaran Komponen Bahan Ajar Statistika Berbasis Literasi Statistik yang Terintegrasi dengan Nilai dan Budaya Keislaman 


\section{Kesimpulan}

Dalam penelitian ini penulis mengembangkan sebuah kerangka konseptual untuk bahan ajar statistika yang terintegrasi dengan nilai dan budaya keislaman. Komponen-komponen yang dirumuskan dalam kerangka konseptual tersebut merupakan hasil sintesis terhadap kajian literatur dalam bidang pendidikan statistika dan bidang keislaman yang dapat dikaitkan dengan statistika maupun pembelajaran statistika. Hasilnya, tiga komponen literasi statistik yang diintegrasikan dengan lima komponen nilai dan budaya keislaman dirumuskan menjadi komponen penyusun kerangka konseptual.

Kerangka konseptual yang dihasilkan dari penelitian ini masih merupakan rancangan tahap awal dan memerlukan lebih banyak perbaikan untuk menuju kesempurnaan. Kerangka ini dapat diujicobakan dalam menyusun materi pembelajaran dan kemudian direvisi atau dikembangkan lagi. Oleh karena itu, diantara penelitian lanjutan yang dapat penulis sarankan untuk pengembangan kerangka tahap awal ini adalah penelitian untuk merancang materi pembelajaran pada suatu topik tertentu dalam mata kuliah statistika dengan berpedoman pada kerangka yang dihasilkan dalam penelitian ini. Selanjutnya dapat dilanjutkan dengan pengujian materi yang telah dirancang tersebut dalam suatu pembelajaran statistika dan melihat efeknya terhadap pemahaman mahasiswa. Kesulitan dan kendala yang dihadapi selama menggunakan materi tersebut juga dapat dijadikan bahan masukan untuk perbaikan kerangka ini. Dengan memfokuskan satu topik, maka kerangka konseptual yang dihasilkan akan mendetail dan memiliki gambaran yang lebih jelas untuk diaplikasikan oleh dosen yang ingin berpedoman pada kerangka ini untuk merancang materi pembelajaran.

\section{Ucapan Terimakasih}

Penyusunan artikel ini dilakukan berdasarkan hasil penelitian yang didukung oleh DANA DIPA 2018 pada IAIN Lhokseumawe. Penulis mengucapkan terima kasih kepada IAIN Lhokseumawe dan tim reviewer atas segala dukungan yang diberikan. 


\section{Daftar Pustaka}

Abdelbasit, Khidir M. "Learning Statistics in a foreign language." Dalam International Encyclopedia of Statistical Science, disunting oleh M. Lovric, 729-30. Berlin, Heidelberg: Springer, 2011.

Abdusysyakir, A. Ketika kyai mengajar matematika. Malang, Indonesia: UINMalang Press, 2007.

Abdusysyakir, A., dan Rosimanidar Rosimanidar. "Model Integrasi Matematika dan Al-Quran serta Praktik Pembelajarannya." Bukit Tinggi, Indonesia, 2017.

Al-Awani, Taha Jabir. Metodologi Hukum Islam Kontemporer. Yogyakarta, Indonesia: UII Press, 2001.

Al-Ghazali. Ihyâ' Ulûmuddîn. Juz 1, t.t.

Aliaga, Martha, George Cobb, Carolyn Cuff, J. B. Garfield, Rob Gould, Robin Lock, Tom Moore, Allan Rossman, Bob Stephenson, dan Jessica Utts. Guidelines for assessment and instruction in statistics education: College report. Vol. 30. California: American Statistical Association, 2005. http://www.amstat.org/education/gaise/.

Ambary, Hasan Mu'arif. "Istiqra'." Dalam Suplemen Ensiklopedi Islam, disunting oleh Abdul Aziz Dahlan. Jakarta: Jakarta: PT Ikhtiar Baru Van Hoeve, 1996.

Amir, Zubaidah. "Integrasi nilai pendidikan islam dalam pendidikan umum sebagai revitalisasi pendidikan islam." Potensia Jurnal Kependidikan Islam 12, no. 1 (2013): 1-22.

Ary, Donald, Lucy Cheser Jacobs, Chris Sorensen, dan Asghar Razavieh. Introduction to Research in Education. 8 ed. California: Wadsworth, 2010.

Bakker, Arthur, dan K. Gravemeijer. "Learning to reason about distribution." Dalam The challenge of developing statistical literacy, reasoning and thinking, disunting oleh Dani Ben-Zvi dan J. B. Garfield, 147-68. Dordrecht, The Netherlands: Kluwer Academic Publishers, 2004. https://doi.org/10.1007/1-4020-2278-6_7.

Ben-Zvi, Dani, Arthur Bakker, dan Katie Makar. "Learning to reason from samples." Educational Studies in Mathematics 88, no. 3 (2015): 291-303.

Borg, W.R, dan M.D Gall. Educational research: An introduction. New York: Longman, 1983.

Burrill, Gail. "Statistical literacy and quantitative reasoning." Dalam Proceedings of the 15th International Conference: Theory and practicean interface or a great divide, 4-9, 2019.

Coladarci, Theodore, Casey D. Cobb, Edward W. Minium, dan Robert C. Clarke. Fundamentals of Statistical Reasoning in Education. NJ: John Wiley \& Sons, Inc., 2004.

delMas, R. "Statistical literacy, reasoning, and thinking: A commentary." Journal of Statistics Education [online] 10, no. 3 (2002). www.amstat.org/publications/jse/v10n3/delmas.html.

Dunn, Peter K., Michael D. Carey, Michael B. Farrar, Alice M. Richardson, dan Christine McDonald. "Introductory Statistics Textbooks and the GAISE 
Recommendations." The American Statistician 0, no. ja (28 Oktober 2016): 0-0. https://doi.org/10.1080/00031305.2016.1251972.

English, Lyn D., dan Jane M. Watson. "Development of probabilistic understanding in fourth grade." Journal for Research in Mathematics Education 47, no. 1 (2016): 28-62.

Franklin, Christine A., dan J. B. Garfield. "The GAISE project: Developing statistics education guidelines for grades pre-K-12 and college courses." Dalam Thinking and reasoning with data and chance: 2006 NCTM yearbook, disunting oleh G. F. Burrill dan P. C. Elliott, 345-76. Reston, VA: National Council of Teachers of Mathematics, 2006.

Gal, Iddo. "Statistical literacy." Dalam The challenge of developing statistical literacy, reasoning and thinking, 47-78. Springer, 2004.

Garfield, J. B. "How students learn statistics." International Statistical Review/Revue Internationale de Statistique, 1995, 25-34.

Garfield, J. B., dan Dani Ben-Zvi. Developing students' statistical reasoning: Connecting research and teaching practice. Springer Science \& Business Media, 2008.

Garfield, J. B., dan Dani Ben-Zvi. "How students learn statistics revisited: A current review of research on teaching and learning statistics." International Statistical Review75, no. 3 (2007): 372-96.

Garfield, J. B., dan Dani Ben-Zvi. "Research on Statistical Literacy, Reasoning, and Thinking: Issues, Challenges, and Implications." Dalam The Challenge of Developing Statistical Literacy, Reasoning and Thinking, disunting oleh Dani Ben-Zvi dan Joan Garfield, 397-409. Springer Netherlands, 2004. http://link.springer.com/chapter/10.1007/1-40202278-6_17.

Garfield, J. B., dan Christine Franklin. "Assessment of learning, for learning, and as learning in statistics education." Dalam Teaching Statistics in School Mathematics-Challenges for Teaching and Teacher Education, disunting oleh Carmen Batanero, Gail Burrill, dan Chris Reading, 133-45. Dordrecht, The Netherlands: Springer, 2011.

Garfield, J. B., Robert del Mas, dan Andrew Zieffler. "Assessing important learning outcomes in introductory tertiary statistics courses." Assessment methods in statistical education: An international perspective, 2010, 75-86.

Graham, Alan. Developing Thinking in Statistics. London: Paul Chapman Publising, 2006.

Hafiyusholeh, Moh. "Literasi Statistik dan Urgensinya Bagi Siswa." Wahana 64, no. 1 (2015): 1-8.

Hanggara, Yudhi, dan Fitrah Amelia. "Pengembangan modul statistik pendidikan berbasis CTL untuk meningkatkan kompetensi mahasiswa universitas riau kepulauan batam." PYTHAGORAS: Jurnal Program Studi Pendidikan Matematika 7, no. 2 (2018): 1-11.

Hiedemann, Bridget, dan Stacey M. Jones. "Learning statistics at the farmers market? A comparison of academic service learning and case studies in an introductory statistics course." Journal of Statistics Education 18, no. 3 (2010). https://doi.org/10.1080/10691898.2010.11889584. 
Idris, Khairiani. "Literasi Statistik Berbasis Konteks Budaya dan Keislaman: Perspektif Dosen dan Mahasiswa PTKI." Dalam Prosiding SI MaNIs, disunting oleh A. Abdusysyakir, 3:[357-362]. Malang, Indonesia: Jurusan Matematika UIN Maulana Malik Ibrahim, 2020.

_-_. "Teaching and Learning Statistics in College: How Learning Materials Should Be Designed." Journal of Physics: Conference Series 1088 (September 2018): 012032. https://doi.org/10.1088/17426596/1088/1/012032.

Idris, Khairiani, dan Kai-Lin Yang. "Analysis of Tasks in Statistics Textbooks for Future English Teachers Based on Statistical Cognitions." Dalam In Pursuit of Quality Mathematics Education for All: Proceedings of the 7th ICMI-East Asia Regional Conference on Mathematics Education. 24674923 (Print) 2467-4931 (Online). Philippines: Philippine Council of Mathematics Teacher Educators (MATHTED), Inc., 2015. http://mathted.weebly.com/.

_- _. "Development and Validation of an Instrument to Measure Indonesian Pre-service Teachers' Conceptions of Statistics." The Asia-Pacific Education Researcher 26, no. 5 (2017): 281-90. https://doi.org/10.1007/s40299-017-0348-z.

Karimah, Nikmatul. "Profil Literasi Statistik Siswa SMA Ditinjau Dari Gaya Kognitif Field dependent Dan Field independent." UIN Sunan Ampel Surabaya, 2017.

Kementrian Agama RI. al-Quran dan Terjemahan. Jakarta: Al-Fadhilah, 2016. Krisdiana, Ika. "Pengembangan Perangkat Pembelajaran pada Matakuliah Statistika Dasar dengan Metode Problem Based Learning." Jurnal Edukasi Matematika dan Sains 4, no. 1 (2016): 61-65.

Krueger, Richard A., dan Mary Anne Casey. Focus groups. Thousand Oaks, CA: Sage, 2000.

Kurniati, A. "Mengenalkan matematika terintegrasi islam kepada anak sejak dini." Suska Journal of Mathematics Education 1, no. 1 (2015): 1-8.

Lancaster, Gillian. "Communicating the Value of Statistical Thinking in Research." Dalam Data and context in statistics education: Towards an evidence-based society, disunting oleh Chris Reading. Ljubljana, Sovlenia: International Association for Statistical Education (IASE), 2010.

Lei, K. K, dan Kai-Lin Yang. "Analysis of statistics content in junior high school mathematics textbooks based on statistical cognition and graph comprehension." Journal of Textbook Research 5, no. 2 (2012): 31-72.

Lukman, Hamidah Suryani, dan Ana Setiani. "Validitas Bahan Ajar Statistika Terapan Berbasis ICT Terintegrasi Proyek." Edumatika: Jurnal Riset Pendidikan Matematika 1, no. 2 (2018): 36-46.

Mahdalena, Mahdalena. Pembelajaran Matematika dan Konsepnya dalam Alquran. Lhokseumawe, Aceh: Unimal Press, 2017.

Mahmood, Abdul Halim. Hal Ihwal Tasawwuf, dari al Munqidz Min al Dlalâl. Diterjemahkan oleh Abu Bakar Basymeleh. Jakarta: Darul Ihya', 1994.

Martadiputra, Bambang Avip Priatna. "Kajian Tentang Kemampuan Melek Statistis Statistical Literacy, Penalaran Statistis Statistical Reasoning , 
Dan Berpikir Statistis Statistical Thinking Guru Smp." abmas 83 (2010). http://jurnal.upi.edu/abmas/view/399/kajian-tentang-kemampuanmelek-statistis--statistical-literacy-,-penalaran-statistis--statisticalreasoning-,-dan-berpikir-statistis--statistical-thinking--guru-smp.

Maryati, Iyam, dan Nanang Priatna. "Analisis Kemampuan Literasi Statistis Siswa Madrasah Tsanawiyah dalam Materi Statistika." Journal of Medives: Journal of Mathematics Education IKIP Veteran Semarang 2, no. 2 (2018): 205-12.

Masduki, Masduki, R. P. Khotimah, dan S. Sutarni. "Islamic values in mathematics learning," 359-69. Yogyakarta, Indonesia, 2014.

Meilisa, Mira, dan Lely Kurnia. "Pengembangan bahan ajar statistika elementer menggunakan aplikasi minitab." Sainstek: Jurnal Sains dan Teknologi 10, no. 2 (2019): 64-69.

Meletiou-Mavrotheris, Maria. "Technological Tools in the Introductory Statistics Classroom: Effects on Student Understanding of Inferential Statistics." International Journal of Computers for Mathematical Learning 8, no. 3 (1 Oktober 2003): 265-97. https://doi.org/10.1023/B:IJC0.0000021794.08422.65.

Moore, David S. "Statistics among the liberal arts." Journal of the American Statistical Association 93, no. 444 (1998): 1253-59.

Moore, David S., George P. McCabe, dan Bruce A Craig. Introduction to the Practice of Statistics. 8th edition. New York: W. H. Freeman, 2014.

Novitasari, Yuni, dan Muhammad Nur. "Bimbingan dan konseling belajar (akademik) dalam perspektif Islam." Indonesian Journal of Educational Counseling 1, no. 1 (2017): 53-78.

Pfannkuch, Maxine, dan Chris Wild. "Towards an understanding of statistical thinking." Dalam The challenge of developing statistical literacy, reasoning and thinking, disunting oleh Dani Ben-Zvi dan J. B. Garfield, 17-46. Netherland: Springer, 2004.

Rossman, Allan, Beth Chance, dan Elsa Medina. "Some important comparisons between statistics and mathematics, and why teachers should care." Dalam Thinking and reasoning with data and chance, disunting oleh Gail Burrill dan P. C. Elliott, 1:323-33. National Council of Teachers of Mathematics, 2006.

Rumsey, Deborah J. "Statistical literacy as a goal for introductory statistics courses." Journal of Statistics Education 10, no. 3 (2002): 6-13.

Rusdiana, A. "Integrasi pendidikan agama islam dengan sains dan teknologi." Istek 8, no. 2 (2014): 123-43.

Sailah, Illah, Tresna Dermawan Kunaefi, Hendrawan Soetanto, I Made Supartha Utama, SP Mursid, Endrotomo Endrotomo, Sylvi Dewajani, dkk. Buku Panduan Kurikulum Pendidikan Tinggi (K-DIKTI). Jakarta: Direktorat Jenderal Pendidikan Tinggi, 2014.

Wallman, Katherine K. "Enhancing statistical literacy: Enriching our society." Journal of the American Statistical Association 88, no. 421 (1993): 1-8.

Wang, Pei-Yu, Brandon K. Vaughn, dan Min Liu. "The impact of animation interactivity on novices' learning of introductory statistics." Computers \& Education 56, no. 1 (2011): 300-311. 

Maret-2021, Vol.9, No.1, hal.29-56

Watson, J. "Curriculum expectations for teaching science and statistics." Dalam Proceedings of the International Conference on Teaching Statistics 9, disunting oleh Katie Makar, B. de Sousa, dan Rob Gould. Flagstaff, AZ: International Association for Statistical Education (IASE), 2014.

Weiland, Travis. "Problematizing statistical literacy: An intersection of critical and statistical literacies." Educational Studies in Mathematics 96, no. 1 (2017): 33-47.

Wiberg, Marie. "Teaching statistics in integration with psychology." Journal of Statistics Education 17, no. 1 (2009): 1-16. https://doi.org/10.1080/10691898.2009.11889509.

Yenni, Yenni, dan Retno Andriyani. "Bahan Ajar Statistika Berbasis Generative Learning untuk Meningkatkan Kemampuan Pemahaman Matematis." Kalamatika: Jurnal Pendidikan Matematika 4, no. 2 (2019): 151-62. 